\title{
GENETIC DIVERSITY IN ACCESSIONS OF Passiflora cincinnata Mast. BASED ON MORPHOAGRONOMIC DESCRIPTORS AND MOLECULAR MARKERS ${ }^{1}$
}

\author{
TIAGO VINÍCIUS BATISTA DO CARMO ${ }^{2 *}$, LUIZA SUELY SEMEN MARTINS ${ }^{3}$, ROSIMAR DOS SANTOS \\ MUSSER $^{2}$, MAIRON MOURA DA SILVA ${ }^{4}$, JOSÉ PEROBA OLIVEIRA SANTOS $^{5}$
}

\begin{abstract}
Passiflora cincinnata Mast. has become more popular in the market because the unusual flavor of its fruits and natural beauty of its flowers, and has great potential for breeding programs of Passiflora edulis f. flavicarpa, because its resistance to diseases and drought. The objective of this work was to evaluate seven wild passion fruit ( $P$. cincinnata) accessions, using morphological and agronomic descriptors and molecular markers type ISSR, to identify their morphoagronomic and genetic variabilities and potential for use in breeding programs. A randomized block experimental design was used with five replications and two plants per plot. Thirteen qualitative and twenty-one quantitative, vegetative and floral characteristics were used for morphoagronomic characterization. Twelve ISSR primers were evaluated for molecular characterization. Among the qualitative characteristics, only the color variations were significantly different between the accessions. According to the mean squares of the quantitative characteristics evaluated, obtained from analysis of variance, the means of accessions showed significant differences $(p<0.01)$ for all characteristics. The IAL (internode average length) was the morphological descriptor that most contributed to diversity, with $43.12 \%$, followed by DH5 (stem diameter at $5 \mathrm{~cm}$ height) and SW (sepal width). The average genetic similarity found was $68 \%$. Despite the low genetic variability found among accessions, the primers UBC-887 and UBC-841 stood out with high percentage of polymorphism with 14 and 11 polymorphic fragments, respectively, and higher values of polymorphism information content (PIC), resolving power (RP) and marker index (MI), denoting suitability for use in diversity studies of $P$. cincinnata. Low variability was found among accessions evaluated.
\end{abstract}

Keywords: Genetic Resources. Plant Breeding. ISSR. Passifloraceae.

\section{DIVERSIDADE GENÉTICA EM ACESSOS DE Passiflora cincinnata Mast. BASEADA EM DESCRITORES MORFOAGRONÔMICOS E MARCADORES MOLECULARES}

RESUMO - A espécie Passiflora cincinnata Mast. vem se popularizando no mercado pelo sabor incomum dos seus frutos, beleza natural de sua flores e possui grande potencial para a cultura de Passiflora edulis $\mathrm{f}$. flavicarpa, pois apresenta resistência a doenças e déficit hídrico. Este trabalho teve como objetivo avaliar sete acessos de maracujá-do-mato ( $P$. cincinnata) por meio de descritores morfológicos, descritores agronômicos e marcadores moleculares do tipo ISSR visando identificar variabilidade morfoagronômica e genética e o potencial para serem utilizados em programas de melhoramento. $\mathrm{O}$ delineamento experimental foi em blocos casualizados, com cinco repetições e duas plantas por parcela. Para caracterização morfoagronômica foram avaliadas 13 características qualitativas e 21 características quantitativas vegetativas e florais. Para caracterização molecular foram testados 12 primers de ISSR. Entre as características qualitativas apenas as variações de coloração apresentaram diferenças marcantes entre os diferentes acessos. De acordo com os quadrados médios obtidos das análises de variância para as características quantitativas avaliadas pode-se ressaltar as diferenças significativas $(\mathrm{p}<0,01)$ entre as médias dos acessos para todos os caracteres avaliados. Verificou-se que para os 21 descritores morfológicos avaliados, o que mais contribuiu para a diversidade foi o MI (média internódio) com 43,12\%, seguido por DH5 (diâmetro das hastes a 5 centímetros do solo) e LS (largura da sépala). A similaridade genética média encontrada foi $68 \%$. Apesar de ser diagnosticada baixa variabilidade genética entre os acessos avaliados, os primers UBC-887 e UBC-841 se destacaram com alto percentual de polimorfismo, com 14 e 11 fragmentos polimórficos respectivamente e valores altos para conteúdo da informação de polimorfismo (PIC), poder de resolução do primer (RP) e índice do marcador (MI) dos primers, demonstrando aptidão para serem utilizados em pesquisas de diversidade em P. cincinnata. Foi diagnosticada baixa variabilidade entre os acessos avaliados.

Palavras-chave: Recursos Genéticos. Melhoramento Genético. ISSR. Passifloraceae.

\footnotetext{
*Corresponding author

${ }^{1}$ Received for publication in $04 / 02 / 2015$; accepted in 06/17/2016.

Paper extracted from the master thesis of the first author.

${ }^{2}$ Department of Agronomy, Universidade Federal Rural de Pernambuco, Recife, PE, Brazil; tvinibatista@gmail.com, rmusser@ufrpe.br.

${ }^{3}$ Department of Biology; Universidade Federal Rural de Pernambuco, Recife, PE, Brazil; luiza@db.ufrpe.br.

${ }^{4}$ Department of Agronomy, Universidade Federal Rural de Pernambuco, Garanhuns, PE, Brazil; maironmoura@uag.ufrpe.br.

${ }^{5}$ Vista Alegre Farm Experimental Unit, Instituto Agronômico de Pernambuco, Brejão, PE, Brazil; peroba.oliveira@ipa.br.
} 


\section{INTRODUCTION}

The Passifloraceae family encompasses 17 genera and a large number of species, surpassing 600. The genera found in Brazil are the Dilkea, Mitostemma and Passiflora, which has approximately 130 species that can be grown for fruit production, candy manufacturing, ornamental purposes and pharmacological products. The yellow passion fruit (Passiflora edulis f. flavicarpa), purple passion fruit (Passiflora edulis) and sweet passion fruit (Passiflora alata) are the most cropped species (ULMER et al., 2004; CERVI, 2005).

Brazil stands out in passion fruit production, especially sour passion fruit (Passiflora edulis Sims), with a production of $714,000 \mathrm{Mg}$ in 2012. The Northeast region accounts for $73 \%$ of the total production, around $524,000 \mathrm{Mg}$. A marked increase in the Northeast production is noticed, considering that in 1996 the region accounted for only $44 \%$ of the national production. This increase is partly due to the increased planted area, the technological improvement and implementation of irrigation, especially in the states of Bahia, Ceara and Sergipe, which produced respectively $317,000,129,000$ and 47,000 Mg of fruits in 2012 (AGRIANUAL, 2012; IBGE, 2014).

Passiflora cincinnata Mast. has great potential for Passiflora edulis f. flavicarpa production (MELETTI et al., 2005), since it can be used as rootstocks and presents resistance to diseases and drought (MELETTI et al., 2002; ARAÚJO, 2007).

The $P$. cincinnata, known as wild passion fruit, is a polymorphous species with variable fruit shape and size, widely distributed in Brazil and very popular in the Northeast (OLIVEIRA; RUGGIERO, 2005). The species has less commercial importance than the Passiflora edulis, but is consumed fresh, marketed in small-scale fairs, especially in Pernambuco and Bahia, and is used for preparation of jams and jellies by small local cooperatives. The plants are vigorous, presenting some resistance genes to biotic and abiotic stresses (COELHO, 2009; FREITAS et al., 2011).

Assessments on genotypes that are collected in different geographic regions, must be carried out in the same environment of the collection for selecting accessions with characteristics for specific purposes, and also require studies on the genetic divergence of the accessions. Native species of Passifloraceae in Brazil have great diversity, thus presents a great potential for identification of genotypes that can be used for food and pharmaceutical production and yellow passion fruit breeding programs (OLIVEIRA JÚNIOR et. al, 2010).

This objective of this work was to evaluate Passiflora cincinnata accessions, using morphological and agronomic descriptors and molecular markers type ISSR.

\section{MATERIAL AND METHODS}

The experiment was conducted from February 2013 to February 2014, at the Experimental Station of the Agronomic Institute of Pernambuco (IPA), Brejão, South Agreste of Pernambuco State $\left(09^{\circ} 01^{\prime} 49 \mathrm{~S}, 36^{\circ} 34^{\prime} 07 \mathrm{~W}\right.$ and altitude of $\left.788 \mathrm{~m}\right)$. The climate was classified as Cs-a mesothermal, with continental, hot and dry summer, according to Koppen and rainy season from January/February to September, which may last until October (LAMEPE/ ITEP, 2011).

The seeds used were from the Coopercuc Uauá BA (Donor Institution) (Accession 1); Cha Grande, PE (Collection Site) (Accession 02); EMBRAPA (Donor Institution) Passiflora Germplasm Bank (PGB) 268 (Accession 03); Viçosa MG (Collection Site) (Accession 04); Jaboticabal SP (Collection Site) (Accession 05); Jaboticabal SP (Collection Site) (Accession 06) and EMBRAPA (Donor Institution) PGB 016 (Accession 07).

The seeds were subjected to immersion for 24 hours in a growth regulator solution (gibberellic acid GA4+7+N-(phenylmethyl)-1-6-aminopurine 1.8\%) to overcome seed dormancy. The seeds were sown in tubes ( 3 seeds per tube) containing $55 \mathrm{~cm}^{3}$ of a commercial substrate (Plantmax $\left.{ }^{\circledR}\right)$, then these tubes were kept in a greenhouse and watered daily.

Seedlings were transplanted to individual black polyethylene bags of $28 \times 14 \mathrm{~cm}$, containing the commercial substrate and identified individually when they reached three pairs of leaves. The nutritional needs of the accessions at seedling were supplied by weekly applications of a nutrient solution containing essential macro and micronutrients.

Seedlings were transplanted to the experimental area 50 days after planting. The experiment was arranged in a randomized block design with seven treatments (accessions) and five replicates, using two plants per plot, spaced $2.0 \mathrm{~m}$ between rows and $4.0 \mathrm{~m}$ between plants. The plots consisted of seven lines, two as borders, considered the five center lines. Vertical espaliers were used for support, with a smooth wire No. 12 at height of $1.7 \mathrm{~m}$, and the planting hole dimensions was $0.40 \times 0.40 \times 0.40 \mathrm{~m}$.

Fertilizations were performed according to soil analysis, following the fertilization recommendations for the State of Pernambuco (IPA, 2008), and a micro-sprinkler system was used for irrigation.

The morphoagronomic descriptors used were those commonly employed for Passifloraceae and the official descriptors for the different Passiflora species (BRASIL, 2008), with changes, as proposed by Araújo et al. (2008) and some other needed changes. The qualitative characteristics evaluated were the color of sepals, petals and inner, outer and intermediate filaments, using the plant tissue color chart of Munsell.

The leaf quantitative characteristics evaluated were the leaf area (LA) $\left(\mathrm{mm}^{2}\right)$, measured with digital direct reading device (Area Meter AM300); Petiole average length (PAL), measured in five petioles; and number of foliar glands (NFG), counted on the abaxial surface of five leaves. 
The flower quantitative characteristics evaluated were bract length (BL), measured in five bracts at pre-anthesis of flowers; number of glands in the bracts (NGB), counted in five bracts at pre-anthesis of flowers; and at anthesis of flowers, the flower diameter (FD), measured from the extreme points of the flower; corona diameter (CD) measured from the extreme points of the corona; outer (OFL) and inner (IFL) filament length from the insertion in the flower receptacle to the apex; filament average length (FAL); petal length (PL) from insertion in the flower to the apex; petal width (PW), measuring the largest dimension; sepals length (SL) from the insertion in the flower to the apex; sepal width (SW), measuring the largest dimension; floral peduncle length (FPL), from the flower receptacle to the insertion in the stem, and bract width (BW) measuring the largest dimension. Five flowers were evaluated in two plants per treatment of the five blocks, totaling 50 flowers per accession, for floral morphological characterization. The evaluations were carried out during the flowering of each accession.

The plant quantitative characteristics evaluated were stem diameter at $0.05 \mathrm{~m}$ (DH5) and $0.10 \mathrm{~m}$ (DH10) above ground; internode average length (IAL), measured up to the height of $1.0 \mathrm{~m}$ from the ground; number of days to reach the espalier (NDRE); number of leaves in the stem (NLS), number of leaves in the main stem when it reached the espalier. Measurements were performed with a digital caliper in millimeters.

Data of number of foliar glands and number of glands in the bracts were processed using the $\sqrt{x}+1$ equation, and the number of days to reach the espalier and number of leaves in the stem were processed using the $\sqrt{\mathrm{x}}$ equation.

The data were subjected to analysis of variance by $\mathrm{F}$ test at $5 \%$ probability, and the significant means were compared by Duncan test at $5 \%$ probability. Following methodology of Singh (1981) the relative contribution of each characteristic were evaluated to assess the genetic diversity of the accessions.

DNA extraction was performed from three grams of leaf tissue of each plant, which were macerated in liquid nitrogen, following the methodology proposed by Doyle and Doyle (1990) with modifications. Five $\mu \mathrm{L}$ of an extraction buffer (4\% CTAB; $100 \mathrm{mM}$ Tris HCL, $\beta$ mercaptoethanol) was added to the macerated material. The samples were subjected to water bath at $60^{\circ} \mathrm{C}$ for 10 minutes for solubilization and homogenization of the suspension.

A washing with chloroform and ethanol (24:1), followed by a centrifugation at $14,000 \mathrm{rpm}$ for 10 minutes, was performed to remove the proteins. The supernatant was subjected to a second washing with chloroform and ethanol and centrifuged again. The aqueous phase was recovered and isopropyl alcohol (volume equal to $2 / 3$ of the initial volume) was added to it for precipitation of nucleic acids. After two hours of resting, the solution was centrifuged for 10 minutes at $14,000 \mathrm{rpm}$. The dry pellet was resuspended in buffer TE $(50 \mathrm{mM}$ of
Tris $+10 \mathrm{mM}$ of EDTA, $\mathrm{pH}$ 8.0) containing RNAse (10 $\eta \mathrm{g} \mathrm{mL}^{-1}$ ) at $37^{\circ} \mathrm{C}$ for one hour. Then, $5 \mathrm{M}$ of $\mathrm{NaCl}$ at 1:10 ( $\mathrm{NaCl}$ : resuspended DNA) and 2/3 of the volume of isopropanol was added to the DNA and incubated at $20^{\circ} \mathrm{C}$ for three hours, and subsequently centrifuged for 10 minutes at $14,000 \mathrm{rpm}$. Then, the dried DNA pellet was again resuspended in buffer TE. After extraction, each sample was quantified $\left(\eta g \mathrm{~L}^{-1}\right)$ in a quantifying device (NanoVue Plus, GE healthcare ${ }^{\circledR}$ ) and stored at $-20^{\circ} \mathrm{C}$. The concentration of each sample was standardized to $50 \eta \mathrm{g} \mu \mathrm{L}^{-1}$.

Amplification reactions were performed to a final volume of $15 \mu \mathrm{L}$, containing $1 \mu \mathrm{L}$ of the template DNA, $0.3 \mu \mathrm{L}$ of Taq DNA polymerase (Invitrogen), $10 \mu \mathrm{L}$ of deionized $\mathrm{H}_{2} \mathrm{O}, 1.5 \mu \mathrm{L}$ of $\mathrm{MgCl}_{2}, 1.2 \mu \mathrm{M}$ of each $\mathrm{dNTP}$, and $1 \mu \mathrm{M}$ of primer. Twelve ISSR primers were evaluated. The DNA amplifications were performed in a thermocycler (MJ Research Inc., Programmable Thermal Controller PTC100, Watetown, USA) under the following conditions: 15 minutes at $95^{\circ} \mathrm{C}$ (initial denaturation); followed by 30 or 35 cycles of 30 seconds at $94^{\circ} \mathrm{C}$ (denaturation); 45 seconds at 49 or $58^{\circ} \mathrm{C}$ (annealing); 2 minutes at $72^{\circ} \mathrm{C}$ (extension) and 7 minutes at $72^{\circ} \mathrm{C}$ (final extension).

The amplification products were separated in a 2.0\% agarose gel, stained with SYBR Gold (Invitrogen), using the molecular weight marker of $100 \mathrm{pb}$ (Invitrogen), visualized under ultraviolet light and recorded in a digital photo-documenter (Vilber Lourmat). The amplification products were tabulated as 1 (presence of bands) and 0 (absence of bands) for the seven accessions. The similarity between all accessions were assessed using the Simple Matching (SM), using a computer program (NTSYSpc 2.01), which generated the matrix of genetic distance between accessions. Dendrograms were developed from the matrix, using groups formed by UPGMA (Unweighted pair Group Method with Arithmetic Average).

The descriptive power of the primers was determined using the following parameters: PIC (polymorphism information content), MI (marker index) and RP (resolving power). The PIC value of each primer was assessed by the formula $P_{I} C_{i}=2 f_{i}\left(1-f_{i}\right)$, where PICi is the PIC of the marker $i$; $\mathrm{f}_{\mathrm{i}}$ is the frequency of present fragments of marker per accession; and $1-f_{i}$ is the frequency of absent fragments. The PIC value average of the fragments of each primer was then found. The MI was assessed by the formula: MI $=$ PIC $\cdot n \cdot n_{p} /\left(n_{p}+n_{m}\right)$, where $n$ is the average number of fragments per primer; $n_{p}$ is the number of polymorphic fragments; and $\mathrm{n}_{\mathrm{m}}$ is the number of monomorphic fragments. The resolving power of each primer was found by the formula $R P=\Sigma I_{b}$, where $I_{b}$ is the level of information of each fragment. The $I_{b}$ is found in a 0-1 scale using the formula: $I_{b}=1-\left(2 \times\left|0,5-f_{i}\right|\right)$ (VARSHNEY et al., 2007). The correlation between the indices found was tested by the Pearson's coefficient using the program BioEstat 5.0.

\section{RESULTS AND DISCUSSION}


Regarding the morphological characteristics of the leaves, all accessions presented pentalobe leaf, with serrated central segment and edges. The accessions 02 and 04 presented obtuse leaf apex and the others presented rounded apex. Two groups were formed, with the leaf apex as the only character of the accessions that differed.

Regarding the shape of outer filaments, two groups were formed, one with five accessions that had ligulate outer filaments of flower, and other with two accessions that had filiform outer filaments of flower (Table 1). The color range of flower filaments in the three series and the sepal and petal color did not allow group distinction (Table 1). Variations in color scales found in the accessions and the natural beauty of flowers, emphasizes the potential of this species for ornamental purposes.

Table 1. Forms of outer filaments and sepal, petals and filaments colors in the three series (outer, intermediate and inner) of flowers of Passiflora cincinnata accessions.

\begin{tabular}{|c|c|c|c|c|c|c|}
\hline \multirow{2}{*}{ Accessions } & \multirow{2}{*}{$\begin{array}{l}\text { Forms of flower } \\
\text { filaments }\end{array}$} & \multicolumn{3}{|c|}{ Flower filament color in the series } & \multirow{2}{*}{ Sepal color } & \multirow{2}{*}{$\begin{array}{l}\text { Petal } \\
\text { color }\end{array}$} \\
\hline & & Outer & Intermediate & Inner & & \\
\hline $\begin{array}{l}\text { 01- DI: Coopercuc } \\
\text { (Uauá/Bahia) }\end{array}$ & Ligulate & $10 \mathrm{P} 6 / 12$ & $5 \mathrm{RP} 6 / 18$ & 7.5RP $3 / 12$ & $5 \mathrm{RP} 8 / 10$ & $10 \mathrm{P} 6 / 4$ \\
\hline 02- CS: Chã Grande/PE & Ligulate & $10 \mathrm{P} 8 / 4$ & $10 \mathrm{P} 9 / 6$ & 10RP $3 / 12$ & 5RP 9/4 & $10 \mathrm{P} 9 / 4$ \\
\hline $\begin{array}{l}\text { 03- DI: EMBRAPA } \\
\text { (PGB-268) }\end{array}$ & Ligulate & $10 \mathrm{P} 5 / 10$ & $10 \mathrm{P} 6 / 16$ & 7.5RP $3 / 10$ & $10 \mathrm{P} 7 / 4$ & $10 \mathrm{P} 5 / 10$ \\
\hline 04- CS: Viçosa/MG & Filiform & $10 \mathrm{P} 3 / 4$ & $5 \mathrm{RP} 7 / 4$ & $7.5 \mathrm{P} 1 / 8$ & $10 \mathrm{P} 3 / 4$ & $10 \mathrm{P} 6 / 6$ \\
\hline 05- CS: Jaboticabal/SP & Ligulate & $7.5 \mathrm{P} 5 / 12$ & $2.5 \mathrm{RP} 5 / 12$ & 10RP $1 / 10$ & 7.5RP7/4 & 10P $9 / 4$ \\
\hline 06- CS: Jaboticabal/SP & Filiform & $5 \mathrm{P} 3 / 6$ & $7.5 \mathrm{RP}$ & $5 \mathrm{RP} 1 / 10$ & $5 \mathrm{P} 8 / 6$ & $5 \mathrm{P} 8 / 8$ \\
\hline $\begin{array}{c}\text { 07- DI: EMBRAPA } \\
\text { (PGB-016) }\end{array}$ & Ligulate & $10 \mathrm{P} 3 / 12$ & $5 \mathrm{RP} 8 / 6$ & $5 \mathrm{RP} 6 / 14$ & $10 \mathrm{P} 7 / 4$ & 5RP 9/6 \\
\hline
\end{tabular}

Donor Institution (DI); Collection site (CS); Passiflora Germplasm Bank (PGB).

The bracts of the accessions were foliaceous and glandular, with an oval shape, and glands present only at the base. All stipules were linear and spiny, with variation only at the edges of the accession 01 (Uauá BA), which had a smooth edge, while the others had serrated edge.

The results of the qualitative morphological characteristics showed little intraspecific variability of the accessions, except for the color of the floral structures.

The mean squares from the analysis of variance of the 21 quantitative characteristics showed significant differences $(p<0.01)$ between accessions (Table 2), denoting a high variability among $P$. cincinnata accessions, and its importance for breeding programs focused in increasing the genetic base, the resistance to diseases caused by bacteria and nematodes and tolerance to drought of Passifloraceae (MELETTI et al., 2002; ARAÚJO, 2007). The coefficient of variation ranged from 4.35 to $17.30 \%$, however, experiments assessing accessions usually have high coefficient of variation for Passifloraceae.

The accession 06 had the highest leaf area $\left(9969.34 \mathrm{~mm}^{2}\right)$ and the accession 03 had the lowest $\left(7169.74 \mathrm{~mm}^{2}\right)$ (Table 3). This characteristic can be used in breeding programs, since this aspect influences photosynthesis, transpiration, solar energy, dry matter production and tolerance to shade.

The highest average of number of glands in the bracts was 6.58 (accession 01) and the lowest was 3.21 (accession 07). The highest average number of foliar glands was 8.40 (accession 06) and the lowest was 7.20 (accession 03) (Table 3).

Nascimento and Barbosa (2014) state that the extrafloral nectaries are an excellent indirect defense strategy, in which the plant draws natural enemies of its herbivores, since the nectar produced is attractive mainly for various arthropod predators. Therefore, studies carried out specific on morphology and tissue composition for a detailed analysis of this defense structure are important.

Regard to the floral descriptors of $P$. cincinnata, the smallest corona diameter (CD) was $101.11 \mathrm{~mm}$ (accession 06) and the largest was $113.90 \mathrm{~mm}$ (accession 04). The flower diameter (FD) ranged from $101.36 \mathrm{~mm}$ (accession 02) to 117.00 $\mathrm{mm}$ (accession 04) (Table 3). Lawinscky et al. (2014) evaluated $P$. cincinnata accessions from the Active Germplasm Bank of the Bahia State University of Santa Cruz (UESC) and found FD variations from 53.81 to $88.93 \mathrm{~mm}$. The lowest 
flower diameter $(12.43 \mathrm{~mm})$ of the accessions evaluated in this work was higher than the largest FD of the mentioned genotype from the UESC Germplasm Bank. Confirming the potential of the accessions to be used in breeding programs focused in the species ornamental potential.

Table 2. Analysis of variance of 21 characters evaluated in seven Passiflora cincinnata accessions using a randomized block experimental design.

\begin{tabular}{llrrrr} 
& & \multicolumn{2}{c}{ Mean Squares } & & \\
\cline { 3 - 5 } Characteristic & Accession & Residue & Mean & CV (\%) \\
\cline { 3 - 5 } & Leaf area & $4186095.42^{*}$ & 2110667.76 & 8396.88 & 17.30 \\
& Petiole average length & $0.64^{*}$ & 0.27 & 4.51 & 11.49 \\
& Internode average length & $1.49^{* *}$ & 0.99 & 5.98 & 16.68 \\
& Number of foliar glands & $0.02^{*}$ & 0.04 & 2.93 & 7.08 \\
\hline Flower & Flower diameter & $111.74^{* *}$ & 21.87 & 107.61 & 4.35 \\
& Filament average length & $24.3^{*}$ & 10.1 & 47.70 & 6.67 \\
& Bract length & $19.65^{*}$ & 7.83 & 31.14 & 8.98 \\
& Number of glands in the bracts & $0.38^{* *}$ & 0.08 & 2.37 & 12.17 \\
& Corona diameter & $93.19^{*}$ & 46.83 & 104.70 & 6.54 \\
& Outer filament length & $44.73^{* *}$ & 9.69 & 40.98 & 7.60 \\
& Inner filament length & $39.55^{* *}$ & 8.29 & 48.21 & 5.97 \\
& Petal length & $25.93^{* *}$ & 3.95 & 45.39 & 4.38 \\
& Petal width & $2.39^{*}$ & 0.79 & 12.07 & 7.38 \\
& Sepal length & $20.18^{* *}$ & 5.14 & 44.26 & 5.12 \\
& Sepal width & $3.64^{*}$ & 2.00 & 16.80 & 8.42 \\
& Floral peduncle length & $120.73^{*}$ & 38.00 & 47.02 & 13.11 \\
& Bract width & $7.46^{*}$ & 2.93 & 14.81 & 11.56 \\
\hline Plant & Number of days to reach the espalier & $23.74^{* *}$ & 1.99 & 8.89 & 15.87 \\
& Stem diameter at 5 cm height & $3.74^{*}$ & 1.10 & 6.64 & 15.82 \\
& Stem diameter at 10 cm height & $3.54^{* *}$ & 0.80 & 5.86 & 15.25 \\
& Number of leaves in the stem & $0.16^{*}$ & 0.12 & 5.45 & 6.37 \\
\hline GL & & 6 & 24 & & \\
\hline
\end{tabular}

$\mathrm{GL}=$ degrees of freedom; $*=$ significant at $5 \%$ by the $\mathrm{F}$ test; $* *=$ significant at $1 \%$ by the $\mathrm{F}$ test; $\mathrm{CV}=$ coefficient of variation.

The outer filament length (OFL) ranged from $37.29 \mathrm{~mm}$ (accession 01) to $44.33 \mathrm{~mm}$ (accession 04 ), and the inner filament length (IFL) from $46.52 \mathrm{~mm}$ (accession 06) to $53.26 \mathrm{~mm}$ (accession 04) (Table 3). The filament average length varied from $44.40 \mathrm{~mm}$ (accession 02) to $51.72 \mathrm{~mm}$ (accession 04) (Table 3). These filaments are fundamental for the interaction with pollinators, since they support the pollinator when collecting nectar. Consequently, accessions without well-formed filaments, or with no adequate filament size to pollinator, have flower pollination and fertilization problems, interfering in the fruit production and perpetuation of their genetic material.

The highest average number of days to reach the espalier (NDRE) was 121.80 (accession 06) and the lowest 37.80 (accession 02) (Table 3). This attribute is highly valued in breeding programs, because it allows to analyze the accession strength, since the shorter the time the accession spent to reach the espalier, stronger the accession is considered.

The stem diameter at 05 and $10 \mathrm{~cm}$ above ground had highest values of $8.01 \mathrm{~mm}$ (accession 02) and 7.30 (accession 02), and lowest values of 5.34 $\mathrm{mm}$ (accession 04) and $4.50 \mathrm{~mm}$ (accession 04), respectively (Table 3 ). These characteristics are important to verify the potential of this species as rootstock, since breeding programs seek to select the accession that most resemble the stem diameter of the commercial species of interest to decrease incompatibility and assist in disease control.

Regarding the relative contribution of the 21 quantitative morphological descriptors evaluated to the genetic diversity of the species, the IAL (internode average length) was the characteristic that most contributed to the diversity, with $43.12 \%$, followed by DH5 (stem diameter at $5 \mathrm{~cm}$ of soil), SW (sepal width) and IFL (inner filament length), totaling $91.23 \%$. The other descriptors had no significant contribution to the divergence, and can be subjected to disposal test. The ranking of contribution for diversity of the 21 characteristics evaluated in $P$. cincinnata accessions is presented in descending order in Table 4. 
Table 3. Average value and standard deviation of mor phological descriptors of Passiflora cincinnata.

\begin{tabular}{|c|c|c|c|c|c|c|c|c|c|}
\hline Accession & \multicolumn{2}{|l|}{$\mathrm{LA}\left(\mathrm{mm}^{2}\right)$} & \multicolumn{2}{|c|}{ PAL $(\mathrm{cm})$} & \multicolumn{2}{|c|}{$\mathrm{IAL}(\mathrm{cm})$} & & NFG & $\mathrm{FD}(\mathrm{mm})$ \\
\hline 01 & \multicolumn{2}{|c|}{$8049.76 \mathrm{ab} \pm 2041.99$} & \multicolumn{2}{|c|}{$4.21 \mathrm{~b} \pm 0.37$} & \multicolumn{2}{|c|}{$6.48 \mathrm{ab} \pm 0.48$} & & $7.56 \mathrm{a} \pm 2.30$ & $106.75 \mathrm{bc} \pm 7.48$ \\
\hline 02 & \multicolumn{2}{|c|}{$8236.40 a b \pm 963.56$} & \multicolumn{2}{|c|}{$4.70 \mathrm{ab} \pm 0.39$} & \multicolumn{2}{|c|}{$6.30 \mathrm{ab} \pm 0.57$} & & $7.50 \mathrm{a} \pm 0.54$ & $101.36 \mathrm{c} \pm 4.45$ \\
\hline 03 & \multicolumn{2}{|c|}{$7169.74 b \pm 1368.79$} & \multicolumn{2}{|c|}{$4.04 \mathrm{~b} \pm 0.37$} & \multicolumn{2}{|c|}{$5.94 \mathrm{ab} \pm 0.35$} & & $7.20 \mathrm{a} \pm 0.79$ & $105.99 \mathrm{bc} \pm 2.66$ \\
\hline 04 & \multicolumn{2}{|c|}{$8438.86 \mathrm{ab} \pm 728.91$} & \multicolumn{2}{|c|}{$4.64 \mathrm{ab} \pm 0.13$} & \multicolumn{2}{|c|}{$6.66 \mathrm{a} \pm 1.07$} & & $7.66 \mathrm{a} \pm 1.73$ & $117.00 \mathrm{a} \pm 3.45$ \\
\hline 05 & \multicolumn{2}{|c|}{$9123.96 \mathrm{a} \pm 888.91$} & \multicolumn{2}{|c|}{$4.42 \mathrm{ab} \pm 1.02$} & \multicolumn{2}{|c|}{$5.09 \mathrm{~b} \pm 1.70$} & & $7.40 \mathrm{a} \pm 0.82$ & $108.39 \mathrm{~b} \pm 5.28$ \\
\hline 06 & \multicolumn{2}{|c|}{$9969.34 \mathrm{ab} \pm 1333.53$} & \multicolumn{2}{|c|}{$5.14 \mathrm{a} \pm 0.39$} & \multicolumn{2}{|c|}{$5.70 \mathrm{ab} \pm 0.90$} & & $8.40 \mathrm{a} \pm 0.48$ & $105.93 \mathrm{bc} \pm 5.09$ \\
\hline 07 & \multicolumn{2}{|c|}{$7790.12 b \pm 2090.25$} & \multicolumn{2}{|c|}{$4.43 \mathrm{ab} \pm 0.55$} & \multicolumn{2}{|c|}{$5.65 \mathrm{ab} \pm 0.92$} & & $7.90 \mathrm{a} \pm 0.28$ & $107.84 \mathrm{bc} \pm 5.73$ \\
\hline Accession & \multicolumn{2}{|l|}{$\mathrm{FAL}(\mathrm{mm})$} & \multicolumn{2}{|c|}{$\mathrm{BL}(\mathrm{mm})$} & \multicolumn{2}{|c|}{$\mathrm{CD}(\mathrm{mm})$} & \multicolumn{2}{|r|}{ NGB } & OFL (mm) \\
\hline 01 & $47.61 \mathrm{ab} \pm 1.36$ & & $31.39 \mathrm{abc} \pm$ & 2.44 & $102.73 \mathrm{~b}$ & \pm 3.05 & & $58 \mathrm{a} \pm 1.32$ & $37.29 \mathrm{c} \pm 3.27$ \\
\hline 02 & $44.40 \mathrm{~b} \pm 3.02$ & & $31.58 \mathrm{abc} \pm$ & 2.96 & $101.79 \mathrm{~b}$ & \pm 4.25 & & $39 \mathrm{ab} \pm 2.68$ & $38.91 \mathrm{bc} \pm 4.02$ \\
\hline 03 & $48.49 \mathrm{ab} \pm 1.74$ & & $28.19 \mathrm{c} \pm 3.2$ & & $104.58 \mathrm{a}$ & \pm 5.58 & & $34 \mathrm{c} \pm 0.50$ & $37.43 \mathrm{c} \pm 0.71$ \\
\hline 04 & $51.72 \mathrm{a} \pm 4.17$ & & $34.01 \mathrm{a} \pm 2.2$ & & $113.90 \mathrm{a}$ & 6.10 & & $40 \mathrm{ab} \pm 0.85$ & $43.03 \mathrm{ab} \pm 1.98$ \\
\hline 05 & $47.89 \mathrm{ab} \pm 3.58$ & & $28.97 b c \pm 2$ & 20 & $103.47 \mathrm{~b}$ & 11.18 & & $22 \mathrm{bc} \pm 1.22$ & $44.33 \mathrm{a} \pm 2.54$ \\
\hline 06 & $46.62 b \pm 3.29$ & & $32.42 \mathrm{ab} \pm 1$ & 95 & $101.11 \mathrm{~b}$ & $=6.67$ & & $33 \mathrm{bc} \pm 1.35$ & $42.56 \mathrm{ab} \pm 2.26$ \\
\hline 07 & $47.20 \mathrm{ab} \pm 3.48$ & & $31.40 \mathrm{abc} \pm$ & 4.90 & $105.33 \mathrm{at}$ & \pm 7.63 & & $21 \mathrm{c} \pm 0.45$ & $43.28 \mathrm{ab} \pm 4.05$ \\
\hline Accession & IFL (mm) & & $\mathrm{PL}(\mathrm{mn}$ & & $\mathrm{PW}(\mathrm{r}$ & & & $(\mathrm{mm})$ & $\mathrm{SW}(\mathrm{mm})$ \\
\hline 01 & $47.10 \mathrm{bc} \pm 1.4$ & & $44.77 \mathrm{bc} \pm$ & 1.96 & $13.23 \mathrm{a}$ & 1.36 & 43.8 & $37 \mathrm{~b} \pm 3.57$ & $18.12 \mathrm{a} \pm 2.42$ \\
\hline 02 & $44.80 \mathrm{c} \pm 2.65$ & & $42.65 \mathrm{c} \pm 2$ & 33 & $11.72 \mathrm{bc}$ & \pm 1.00 & 42.5 & $3 b \pm 2.33$ & $16.49 \mathrm{ab} \pm 0.66$ \\
\hline 03 & $46.71 b c \pm 1.69$ & & $44.00 \mathrm{bc} \pm$ & 1.42 & $12.83 \mathrm{ab}$ & \pm 0.72 & 41.6 & $8 b \pm 2.21$ & $17.71 \mathrm{ab} \pm 0.72$ \\
\hline 04 & $53.26 \mathrm{a} \pm 2.49$ & & $49.95 \mathrm{a} \pm 1$ & 11 & $11.65 \mathrm{bc}$ & \pm 1.18 & 47.9 & $4 \mathrm{a} \pm 2.18$ & $16.89 a b \pm 0.87$ \\
\hline 05 & $50.00 \mathrm{ab} \pm 3.86$ & & $44.91 \mathrm{bc} \pm$ & .81 & $11.83 \mathrm{bc}$ & \pm 0.55 & 44.0 & $7 \mathrm{~b} \pm 1.16$ & $15.80 \mathrm{~b} \pm 1.67$ \\
\hline 06 & $46.52 \mathrm{bc} \pm 2.65$ & & $45.84 \mathrm{bc} \pm$ & 1.59 & $11.31 \mathrm{c}$ & 0.66 & 44.9 & $5 \mathrm{~b} \pm 1.47$ & $16.00 \mathrm{~b} \pm 1.80$ \\
\hline 07 & $49.08 \mathrm{~b} \pm 4.14$ & & $45.59 \mathrm{c} \pm 2$ & 93 & $11.95 \mathrm{bc}$ & \pm 1.18 & 44.7 & $5 \mathrm{~b} \pm 2.97$ & $16.61 \mathrm{ab} \pm 0.96$ \\
\hline Accession & FPL (mm) & & $3 \mathrm{~W}(\mathrm{~mm})$ & & & DH5 (n & & DH10 (mm) & NLS \\
\hline 01 & $53.25 \mathrm{a} \pm 5.75$ & & $9 \mathrm{ab} \pm 3.62$ & 55.60 & \pm 33.72 & $6.43 \mathrm{ab}$ & & $5.64 \mathrm{ab} \pm 1.00$ & $30.10 \mathrm{a} \pm 4.76$ \\
\hline 02 & $54.05 \mathrm{a} \pm 9.11$ & 14.3 & $2 b \pm 1.42$ & 121.80 & \pm 29.54 & $8.01 \mathrm{a} \pm$ & & $7.30 \mathrm{a} \pm 1.08$ & $31.80 \mathrm{a} \pm 3.65$ \\
\hline 03 & $45.28 \mathrm{ab} \pm 2.61$ & 13.2 & $8 \mathrm{~b} \pm 1.28$ & 106.80 & \pm 43.05 & $6.62 \mathrm{ab}=$ & 0.35 & $6.02 \mathrm{ab} \pm 0.10$ & $28.10 \mathrm{a} \pm 2.16$ \\
\hline 04 & $41.31 \mathrm{~b} \pm 4.75$ & 16.8 & $1 \mathrm{a} \pm 1.16$ & 42.80 & \pm 11.84 & $5.34 \mathrm{~b} \pm$ & & $4.50 \mathrm{~b} \pm 0.61$ & $31.20 \mathrm{a} \pm 2.22$ \\
\hline 05 & $42.81 \mathrm{~b} \pm 6.29$ & 13.8 & $30 \mathrm{~b} \pm 1.08$ & 104.90 & \pm 30.75 & $7.34 \mathrm{ab}$ & 1.58 & $6.27 \mathrm{a} \pm 1.40$ & $31.80 \mathrm{a} \pm 4.04$ \\
\hline 06 & $45.20 \mathrm{ab} \pm 4.62$ & 15.2 & $29 \mathrm{ab} \pm 1.25$ & 37.80 & \pm 6.58 & $6.01 \mathrm{ab}$ & 0.94 & $5.57 \mathrm{ab} \pm 0.74$ & $26.90 \mathrm{a} \pm 2.70$ \\
\hline 07 & $47.20 \mathrm{ab} \pm 6.18$ & 14.3 & $9 \mathrm{~b} \pm 1.25$ & 124.20 & \pm 20.45 & $6.70 \mathrm{~b} \pm$ & 77 & $5.75 \mathrm{ab} \pm 0.45$ & $28.80 \mathrm{a} \pm 4.80$ \\
\hline
\end{tabular}

Leaf area (LA); petiole average length (PAL); internode average length (IAL); number of foliar glands (NFG); flower diameter (FD); filament average length (FAL); bract length (BL); number of glands in the bracts (NGB); corona diameter (CD); outer filament length (OFL); inner filament length (IFL); petal length (PL); petal width (PW); sepal length (SL); sepal width (SW); floral peduncle length (FPL); bract width (BW); number of days to reach the espalier (NDRE); stem diameter at $5 \mathrm{~cm}$ height (DH5); stem diameter at $10 \mathrm{~cm}$ height (DH10); number of leaves in the stem (NLS). Data were subjected to analysis of variance by the $\mathrm{F}$ test at $5 \%$ of probability and the means were compared by the Duncan test at $5 \%$ of probability. 
Lima et al. (2012) evaluated the genetic divergence between sour passion fruit genotypes and found the stem diameter at $5 \mathrm{~cm}$ soil also as the second feature that most contributed to the genetic divergence of passion fruit genotypes. Negreiros et al. (2007), evaluated the genetic diversity of yellow passion fruit progenies, based on morphoagronomic characteristics and found the stem diameter as the characteristic that most contributed to the genetic divergence. Araújo et al. (2008) found that the characters that most contributed to the genetic diversity were the total fruit weight $(42.29 \%)$, pollen viability $(8.62 \%)$, leaf area $(7.17 \%)$ and number of glands in the bracts $(5.88 \%)$.

Table 4. Relative contribution of the descriptors for the divergence between the Passiflora cincinnata accessions evaluated, following the method of Singh (1981).

\begin{tabular}{lc}
\hline \multicolumn{1}{c}{ Descriptor } & Contribution (\%) \\
\hline Internode average length (IAL) & 43.120 \\
Stem diameter at 5 cm height (DH5) & 21.270 \\
Sepal width (SW) & 17.230 \\
Inner filament length (IFL) & 9.610 \\
Number of glands in the bracts (NGB) & 3.330 \\
Corona diameter (CD) & 1.760 \\
Number of days to reach the espalier (NDRE) & 1.020 \\
Flower diameter (FD) & 0.900 \\
Leaf area (LA) & 0.700 \\
Sepal length (SL) & 0.080 \\
Floral peduncle length (FPL) & 0.076 \\
Outer filament length (OFL) & 0.027 \\
Petal width (PW) & 0.025 \\
Stem diameter at 10 cm height (DH10) & 0.023 \\
Bract width (BW) & 0.023 \\
Petiole average length (PAL) & 0.023 \\
Number of leaves in the stem (NLS) & 0.019 \\
Filament average length (FAL) & 0.015 \\
Bract length (BL) & 0.001 \\
Petal length (PL) & 0.001 \\
Number of foliar glands (FG) & 0.001 \\
\hline
\end{tabular}

According to the molecular analyzes, the selected primers amplified 81 DNA fragments (Table 5), from which $53(65.43 \%)$ were polymorphic, with average of 7.36 fragments per primer. The primer UBC-810 resulted in fewer amplified fragments (3), and the UBC-887 resulted in the largest number of fragments (15), thus, a high degree of polymorphism. The average of polymorphic fragments amplified per primer was 4.81. The polymorphic fragments varied from 01 (UBC-881) to 14 (UBC-887), with percentage ranging from $16.67 \%$ to $100 \%$.

Table 5. ISSR primer sequence selected, annealing temperatures adopted, number of cycles, number of amplified fragments and number of polymorphic amplified fragments of Passiflora cincinnata accessions.

\begin{tabular}{llcccc}
\hline & & & & \multicolumn{2}{c}{ Number of fragments } \\
\cline { 5 - 6 } Primer & Sequence & & $\begin{array}{c}\text { Number } \\
\text { of } \\
\text { cycles }\end{array}$ & Amplified & Polymorphic \\
\hline UBC-3 & AGTCAGCCAC & 50.3 & 35 & 8 & 5 \\
UBC-808 & (AG)8-C & 57.7 & 35 & 4 & 2 \\
UBC-810 & (AG)8-T & 56.2 & 35 & 3 & 3 \\
UBC-811 & (AG)8-C & 53.7 & 35 & 8 & 4 \\
UBC-812 & (GA)8-A & 55.4 & 35 & 6 & 3 \\
UBC-822 & (TC)8-A & 55.4 & 35 & 6 & 4 \\
UBC-841 & (GA)8-YC & 49.0 & 35 & 11 & 2 \\
UBC-866 & (CT)8-C & 50.0 & 35 & 8 & 1 \\
UBC-881 & GGG-(TGGGG)2-TG & 50.0 & 35 & 6 & 14 \\
UBC-887 & DVD-(TC)6-T & 53.7 & 35 & 15 & 4 \\
UBC-891 & HVH-(TG)7 & 50.0 & 35 & 6 & 2 \\
\hline
\end{tabular}

The average similarity found was $68 \%$, which is consistent with the differences between the accessions analyzed in the study from the distances and grouping analysis.

Accessions from natural populations of $P$. cincinnata, a germplasm bank and large areas of cultivation were used for this experiment, however, differentiate them was not possible because there are still no registered cultivars for this species.

Loss et al. (2006) found low genetic diversity in Passiflora alata, populations, with greater diversity within populations and none between populations. These authors related this result to the pollen self-incompatibility system of the genus 
Passiflora, which induces cross-pollination and thus, increases the species pollination index of the same population and genetic variability.

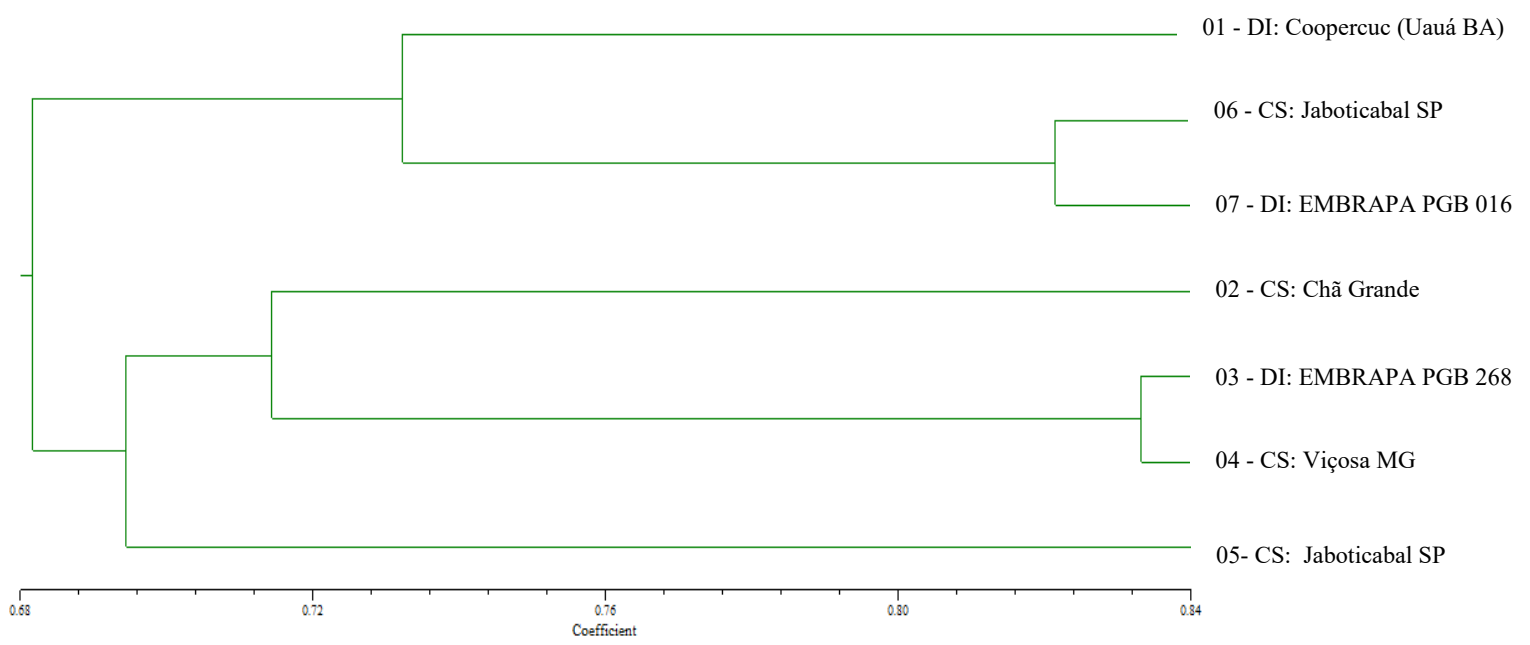

Figure 1. Dendrogram of genetic similarity of Passiflora cincinnata accessions, obtained by ISSR analysis, using the complement of the Jaccard's similarity index and the UPGMA method.

The variability within the Passiflora cincinnata population, the results found in this work, the dendrogram (Figure 1), the fact that the accession 05 is not in the same subgroup of accession 06 (from seeds collected in Jaboticabal SP) and accession 07 is not in the same subgroup of accession 03 (from Embrapa), may indicate greater genetic distance between them.

The cophenetic coefficient of correlation was
$70 \%$, denoting an appropriate relationship between genetic distances and the clusters obtained from the accessions.

The polymorphism information content (PIC) ranged from 0.040 (UBC-881) to 0.393 (UBC-841), with average of 0.220 (Table 6). The primers UBC-841, UBC-887, UBC-810 and UBC-822 had the highest PIC with $0.393 ; 0.391 ; 0.299$ and 0.244 , respectively (Table 6).

Table 6. Polymor phism information content (PIC), resolving power (RP) and marker index (MI) of the primers used in study of Passiflora cincinnata accessions.

\begin{tabular}{cccc}
\hline Primer & PIC & MI & RP \\
\hline UBC-808 & 0.163 & 0.393 & 1.306 \\
UBC-03 & 0.244 & 0.737 & 3.918 \\
UBC-810 & 0.299 & 1.442 & 1.795 \\
UBC-811 & 0.204 & 0.491 & 3.265 \\
UBC-812 & 0.176 & 0.426 & 2.122 \\
UBC-866 & 0.122 & 0.147 & 1.959 \\
UBC-891 & 0.139 & 0.449 & 1.959 \\
UBC-822 & 0.244 & 0.786 & 2.938 \\
UBC-881 & 0.040 & 0.032 & 0.489 \\
UBC-841 & 0.393 & 1.895 & 8.653 \\
UBC-887 & 0.391 & 1.762 & 11.755 \\
\hline Mean & 0.220 & 0.779 & 3.651 \\
\hline
\end{tabular}

The average MI of primers was 0.779 , ranging from 0.032 (UBC-881) to 1.895 (UBC-841), with strong positive correlation with PIC ( $\mathrm{r}=0,98$, $\mathrm{p}<0.0001)$. The resolving power ranged from 0.489 (UBC-881) to 11.755 (UBC-887), with strong positive correlation with PIC $(\mathrm{r}=0.8402, \mathrm{p}=0.0012)$. A positive correlation was also found between IM and RP ( $\mathrm{r}=0.8124, \mathrm{p}=0.0024)$. Positive correlations indicate that the use of any of the parameters is effective to describe the more efficient primers to differentiate accessions (TATIKONDA et al., 2009).

PIC values for biallelic markers was $0.5(0.45$ to 0.5 are PIC values of primers considered very informative). Most primers had PIC values considered high. The primers UBC-810, $841 \mathrm{UBC}$, UBC-887 and UBC-03 were considered the most informative and are recommended for germplasm analysis of $P$. cincinnata. Moreover, PIC values were highly correlated with the number of polymorphic loci $(\mathrm{r}=0.9107 \mathrm{p}=0.3007)$ and can be considered as informative markers for variability studies, according Tatikonda et al. (2009). PIC was also positive correlated to the frequency of polymorphic loci $(\mathrm{r}=0.9107 \mathrm{p}<0.0001)$.

The primers UBC-810, UBC-841 and UBC- 887 had high values of MI and the highest 
percentages of polymorphisms, standing out for diversity studies of Passifloraceae. High RP values, with positive correlations with PIC and MI indicate high descriptive potential of diversity between accessions.

The morphological characterization allowed better understand of the dynamics and possible functions of the accessions and to infer which breeding programs would be of interest in the future. New studies are necessary with the addition of more descriptors, however, the molecular characterization here supports the results obtained with the morphoagronomic descriptors. The association of morphological and molecular characterizations are interesting for researches on accessions to obtain more credible conclusions.

\section{CONCLUSION}

Significant qualitative variation was observed only in the color of floral structures.

Quantitative variations was observed in vegetative and floral structures.

Low variability between accessions were found.

The primers UBC- 887 and UBC-841 stood out with the highest values for PIC, MI and RP, denoting their suitability for use in diversity researches of $P$. cincinnata.

\section{REFERENCES}

ARAÚJO, F. P. Caracterização da variabilidade morfoagronômica de maracujazeiro (Passiflora cincinnata Mast.) no semi-árido brasileiro. 2007. 94 f. Tese (Doutorado em Horticultura) Universidade Estadual Paulista, Botucatu, 2007.

ARAÚJO, F. P.; SILVA, N.; QUEIROZ, M. A. Genetic divergence among Passiflora cincinnata Mast. accessions based on morphoagronomic descriptors. Revista Brasileira de Fruticultura, Jaboticabal, v. 30, n. 3, p. 723-730, 2008.

BRASIL. Ministério da agricultura e do Abastecimento. SNPC - Instruções para execução dos ensaios de distinguibilidade, homogeneidade e estabilidade de cultivares de maracujá das espécies Passiflora alata Curtis; Passiflora amethysina J.C.Mikan; Passiflora caerulea L.; Passiflora cincinnata Mast.; Passiflora coccinea Aubl.; Passiflora foetida L.; Passiflora gardneri Mast.; Passiflora ligularis Juss.; Passiflora mucronata Lam.; Passiflora nitida Bonpl. ex Kunth; Passiflora quadrangularis L.; Passiflora setacea DC.; Passiflora tenuifila Killip e Passiflora tripartita (Juss.) Poir., (abrangindo cultivares ornamentais, medicinais, frutíferas e híbridos interespecíficos). Disponível em: < http:// www.agrolink.com.br/downloads/dou2 18-1208.pdf $>$. Acesso em: 19 jun. 2012.

CERVI, A. C. Espécies de Passiflora $L$.
(Passifloraceae) publicadas e descritas nos últimos 55 anos (1950-2005) na América do Sul e principais publicações brasileiras. Estudos de Biologia, Curitiba, v. 27, n. 61, p. 19-24. 2005.

COELHO, M. S. E. Caracterização citogenética de Passiflora edulis f. flavicarpa Deg. P. cincinnata Mast. e seu híbrido interespecífico. 2009. 67 f. Dissertação (Mestrado em Agronomia) Universidade Federal da Paraíba, Areia, 2009.

DOYLE, I. J.; DOYLE, J. L. Isolation of plant from fresh tissue. Foccus, Rockville, v. 12, n. 1, p. 13-15, 1990.

FNP. AGRIANUAL 2012: Anuário da agricultura brasileira. São Paulo, SP: OESP, 2012. 349-350 p.

FREITAS, J. P. X. et al. Avaliação de recursos genéticos de maracujazeiro-amarelo. Pesquisa Agropecuária Brasileira, Brasília, v. 46, n. 09, p. 1013-1020, 2011.

IBGE. Instituto Brasileiro de Geografia e Estatística. Produção Agrícola. Disponível em: $<\mathrm{http} / /$ www.ibge.gov.br>. Acesso em: 20 julho 2014.

IPA - Instituto Agronômico de Pernambuco. Recomendações de adubação para o estado de Pernambuco. 2. ed. Recife: Instituto Agronômico de Pernambuco, 2008. 198 p.

LAMEPE/ITEP - Laboratório de Meteorologia de Pernambuco/Instituto de tecnologia de Pernambuco. Informações climáticas do Estado de Pernambuco. Recife, 2011. Disponível em: $<$ http://www.itep.br/>. Acesso em: 21 ago. 2012.

LAWINSCKY, P. R. et al. Morphological characterization and genetic diversity in Passiflora alata Curtis and $P$. cincinnata Mast. (Passifloraceae). Brazilian Joumal of Botany, São Paulo, v. 37, n. 3, p 261-272, 2014.

LIMA, D.T. et al. Divergência genética entre genótipos de maracujazeiro azedo com base em vigor, incidência de doenças e características de frutos. Revista Magistra, Cruz das Almas, v. 24, n. 4, p. 314-322, 2012.

LOSS, A. C. C. et al. Diversidade genética de populações de maracujá-doce (Passiflora alata Curtis) no estado do Espírito Santo, Brasil. Natureza on line, Santa Teresa, v. 4, n. 2, p. 55-61, 2006.

MELETTI, L. M. M. et al. Melhoramento genético do maracujá: passado e futuro. In: FALEIRO, F. G.; JUNQUEIRA, N. T. V.; BRAGA, M. F. (EdS.). Maracujá: germoplasma e melhoramento genético. Planaltina: Embrapa Cerrados, 2005. v. 1 , cap. 3 , p. $55-78$.

MELETTI, L. M. M. et al. Novas tecnologias melhoram a produção de mudas de maracujá. O Agronômico, Campinas, v. 54, n. 1, p. 30-33, 2002. 
NASCIMENTO, K. C.; BARBOSA, J. F. Caracterização morfoanatômica de nectários extraflorais de Passiflora alata, Passifloraceae. Revista Uningá Review, Maringá, v. 20, n. 1, p. 45 $-55,2014$.

NEGREIROS, J. R. S. et al. Diversidade genética entre progênies de maracujazeiro amarelo baseado em características morfoagronômicas. Revista Ceres, Viçosa, v. 54, n. 312, p. 153-160. 2007.

OLIVEIRA, J. C.; RUGGIERO, C. Espécies de Maracujá com potencial agronômico. In FALEIRO, F. G.; JUNQUEIRA, N. T. V.; BRAGA, M. F. (Eds.). Maracujá Germoplama e melhoramento genético. Brasília: Embrapa Cerrados, 2005. v. 1, cap. 6 , p. 141-158.

OLIVEIRA JÚNIOR, M. X. et al. Superação de dormência de maracujá-do-mato (Passiflora cincinnata MAST.). Revista Brasileira de Fruticultura, Jaboticabal, v. 32, n. 2, p. 584-590, 2010.

SINGH, D. The relative importance of characters affecting genetic divergence. The Indian Joumal of Genetics e Plant Breeding, New Delhi, v. 41, n. 1, p. $237-245,1981$.

TATIKONDA L. et al. AFLP-based molecular characterization of an elite germplasm collection of Jatropha curcas L., a biofuel plant. Plant Science, Chicago, v. 176, n. 4, p. 505-513, 2009.

UlMER, T.; MACDOUGAL, J. M. Passiflora: Passionflowers of the world. Portland, OR: Timber Press, 2004. 430 p.

VARSHNEY R. K et al. Comparative assessment of EST-SSR, EST-SNP and AFLP markers for evaluation of genetic diversity and conservation of genetic resources using wild, cultivated and elite barleys. Plant Science, Chicago, v. 173, n. 1, p. 638649, 2007. 